Women's Studies

An interdisciplinary journal

\title{
'The Bird / Who Sings the Same, Unheard, / As Unto Crowd -': Dickinson, Birdsong, and the Business of Improvisation
}

\section{Gerard Holmes}

To cite this article: Gerard Holmes (2021): 'The Bird / Who Sings the Same, Unheard, / As Unto Crowd -': Dickinson, Birdsong, and the Business of Improvisation, Women's Studies

To link to this article: https://doi.org/10.1080/00497878.2020.1865352

$$
\text { 曲 Published online: } 21 \text { Jan } 2021 .
$$

$\sqrt{6}$ Submit your article to this journal ๘

Q View related articles $₫$

View Crossmark data $\circlearrowright$ 


\section{'The Bird / Who Sings the Same, Unheard, / As Unto Crowd -': Dickinson, Birdsong, and the Business of Improvisation}

\section{Gerard Holmes}

University of Maryland, College Park

One sob in the throat, one flutter of bosom - "My business is to sing" - and away she rose! (L269)

Perhaps you smile at me. I could not stop for that - My Business is Circumference -. (L268)

"... a word of extensive use and indefinite signification ... ." Noah Webster, "Business," American Dictionary of the English Language (italics in original)

Birds are everywhere in nineteenth-century American literature, including the work of Emily Dickinson. The poem that lends several lines to this essay's title, "To hear an Oriole sing" (Fr402), is one of 222, about one in eight of the extant poems, in which Dickinson mentions birds or their songs (Schuman and Hodgman xvi). She named 26 distinct species (xiii). Scholars of the period have long associated birdsong with Romantic and sentimentalist themes, and Dickinson scholarship is no exception. Cheryl Walker points out the ways that the myth of Philomela, turned into a nightingale by Tere3us, agonizingly sorrowful but unable to sing because tongueless, inflected American women's poetry and women poets' sense of their own projects in the eighteenth and nineteenth centuries. There are no nightingales in the Americas, but associations between the species and improvisation traveled from Europe, because of its remarkable ability to spontaneously combine fragments of song in seemingly infinite varieties. Walker and other feminist critics radically recontextualized the canonical Dickinson by reading her alongside then-dismissed poets such as Elizabeth Oakes Smith and Lydia Huntley Sigourney. Walker contrasts Dickinson with her friend Helen Hunt Jackson, characterizing Jackson as a careerist, where Dickinson is presented as more characteristic of the sentimental poetess, her work reflecting "the vulnerability or ambivalence toward freedom characteristic of women's bird poems" (49). Contrasting Dickinson with the still too-little studied Jackson and others had a profound effect on nineteenth-century Americanist scholarship, prompting the rediscovery, reprinting, and

CONTACT Gerard Holmes gholmes@umd.edu English Department, 2205 Tawes Hall, University of Maryland, College Park, MD 20742.

(c) 2021 Taylor \& Francis Group, LLC 
inclusion in literature courses of these women poets and their work for subsequent generations of readers.

This essay offers a rethinking of the birds in Dickinson's letters and poems. It is less concerned with how Dickinson hewed to or resisted popular mythic or sentimentalist representations of birds and their songs. Instead, it suggests that Dickinson's birds, and her descriptions of their songs, show her awareness of business even if, unlike Jackson, she was not writing for money. Dickinson's birds often appear in the guises of familiar kinds of workers, and their songs as a kind of performative labor with which she, as a writer, identified. Her method, not only of writing but of sharing that writing with a largely self-selected audience, resulted in a creative community similar to that of the birds represented in the letters and poems discussed below. In the critical literature, to the extent that Dickinson's awareness of business has been discussed at all, she has been represented as what Betsy Erkkila called "the privileged daughter of the town squire" (2), alternately compliant with or resistant to, but certainly not much interested in, business. I argue that her writings about birds and their songs show her awareness of how money inflects cultural activity, including the business of writing. The songs sung by Dickinson's birds signal them as workers within avian communities, and function both as a form of work and as a means of negotiating and establishing the ties of common understanding and employment within which they are sung.

Their communities are often cooperative and performative: it is by singing that birds demonstrate the communitarian purpose of song. The types and variety of workers represented invoke the kinds of domestic and creative communities within which the poet herself lived and worked, and they also show something about how she conceived of her own "business," the writing of poems. Beginning in the late 1850s and early 1860s, when Dickinson was in her twenties, her epistolary network increasingly extended beyond an established set of friends and family to include professional writers. She built this network by means of letters and poems whose writing and distribution may be read as a form of business communication. In doing so, she constructed a creative community outside the print-based systems of exchange that increasingly characterized writer's lives in the middle of the nineteenth century. As this happened, her "song" - and like many writers of her time, she uses this and similar terms to refer to her writing - eventually passed somewhat out of her control, the way a bird's song travels outward to, and then beyond, its intended audience.

During Dickinson's lifetime, ornithology was becoming professionalized, and birdsong a subject of scientific study. Like her correspondent, the clergyman, writer, and editor Thomas Wentworth Higginson, Dickinson was an amateur bird-watcher, not a scientist. Both understood birdsong as a robust form of communication among birds, but each understood birdsong 
differently in at least one respect. Higginson described it as incomprehensible to human listeners, while Dickinson's letters and poems present birdsong as comprehensible and even broadly translatable. In her poems and letters, the communities birds create through song are capacious enough to include human listeners. In other words, Dickinson understood herself to participate as a listener to and interpreter of the communication encoded in birdsong. Sharing these translations with her correspondents brought her and them into a broader circle of communication, even if she and they were not the intended audience of the birds' songs. In this way, the avian communities Dickinson represents in her poems and letters provide a model for the kind of distant, cohesive but porous, social and creative network she imagined, and brought into being, in her own writing practice.

Dickinson's imagined world of bird-song-work, and the creative community the poet brought into being by means of these letters and poems, evoke a model of societal interaction that is voluntary and spontaneously selforganizing: an anarchist or socialist model, as these terms were understood in Massachusetts in the 1840s, in utopian and cooperative communities such as Brook Farm in West Roxbury, and Fruitlands in Harvard. Such experimental communities were performative, intended to demonstrate new modes of affiliation, integrating manual labor with creative work, productive equally of vegetables and poems. Words and music were essential to these communities, which were also businesses, if often poorly managed ones. ${ }^{1}$ Words were integrated with manual labor, intended to produce tangible results, a remade society. But words cannot make cucumbers grow, as songs do not build nests. Well-known in Massachusetts during Dickinson's lifetime, their ambitions and failures became legendary, providing models and cautions for subsequent self-organizing communities. Like the writers who joined and left them, Dickinson's birds continually renegotiate their selforganizing networks of communication, migrating, singing, integrating and reintegrating themselves into communities by means of extemporaneous, casual, but meaningful singing. Dickinson herself continually negotiated and renegotiated her creative community through the act of writing.

Throughout this essay, I prefer the word "business" to related terms such as commerce, profession, and labor, because it is the term she chose in writing to Higginson and to family friends Josiah and Elizabeth Holland Josiah was also an influential writer-editor - in two letters dating from 1862. "Business" was and remains a surprisingly slippery term, with a range of possible meanings. Dickinson's birds enact a real variety of work-related activities: some are recognizably laborers, others transact commerce, are associated with recognizable professions, or participate in avocational or

${ }^{1}$ Participants in Brook Farm included John Sullivan Dwight, founder and publisher of the influential Dwight's Journal of Music. 
volunteer work, such as sextons or choristers. Not all of these are commercial, professional, or labor activities, but all participate in some form in business. This capaciousness of meaning may be why Dickinson chose the term. She was no stranger to business, as the daughter and sister of lawyers; as someone who saw the personal involvement of her grandfather, father, and brother in the growth of a private college in her town; as a musically engaged person who commented on some of the most popular professional musicians of her time; and most importantly, as a writer who regularly corresponded with professional writers and editors. ${ }^{2}$

Her awareness of the workings of business was no doubt honed by observing business decisions made by her lawyer grandfather and father, and not always wise ones. Far from a coddled squire's daughter, Dickinson was well aware of business communications networks, and of the transactions that underlay them. Her family's significant financial reversal during the poet's childhood, and her grandparents' self-exile west to Cincinnati in 1833, gave Dickinson good reason to remain cognizant of the business of print publishing, even as she largely eschewed print herself. Instead, she created an alternative publication network, bringing Higginson, Josiah Holland, and others into a network of ongoing, multidirectional communication, inviting them to "sing" back to her. Throughout this essay, I read Dickinson's letters alongside, and of equivalent importance with, the poems. Dickinson herself troubled the generic distinction between the two, sometimes including poems with letters, sometimes interpolating them within letters.

Dickinson's knowledge of business matters, including the business of print, is evident in her remark to Higginson in 1866, "I had told you I did not print" (L316). Dickinson is "deliberate, not desperate" in distinguishing between publishing and print (Smith 16). Her concern is that Higginson might recognize as hers the poem that had recently appeared anonymously under as "The Snake," in the Springfield Republican, and reprinted elsewhere, and "think me ostensible," that is, merely pretending to be the person she presented herself to be in letters. The poem published as "The Snake," "A narrow Fellow in the Grass," includes the lines, "He likes a boggy acre,/A floor to cool for corn" (Fr1096). A note to the poem, numbered 986 in Thomas Johnson's variorum edition, indicates Dickinson's subtle employment of her business knowledge. Samuel Bowles, editor of the Republican, "is reported to have exclaimed, 'How did that girl ever know that a boggy field wasn't good for corn?"”

\footnotetext{
${ }^{2}$ The word "business" appears nineteen times in Dickinson's letters, including twice each in the two letters discussed below. Many refer to the work of others, or to business dealings generally. During the period discussed here, she seems particularly concerned with women's self-generated employment. In 1863, she jokes with her nieces Louise and Frances Norcross that she "found a milliner's case in Miss N[orcross]'s wardrobe, and have opened business" (L285). Dickinson's concern with "business" was timely. During the Civil War years, women entered the paid workforce in increasing numbers. Virginia Penny's 1863 Employments for Women: A Cyclopedia cataloged 516 distinct employments for women in the U.S.
} 
Another, more distant model and cautionary tale when it came to the financial implications of creative production was the Swedish opera singer Jenny Lind, whose 1850-1852 U.S. tour generated unprecedented wealth for herself and the tour's promoter, P.T. Barnum. Lind was marketed as guileless and unconcerned with money. Ironically, Lind's unworldly public persona, and her private attention to finances, was instrumental in her earning enough on the tour to retire from singing at age thirty-two. Barnum characteristically created profitable spectacle, with which Lind seems to have grown increasingly uncomfortable. One year into the tour, she exercised an option to break ties with Barnum, but continued touring for nearly another year, under her own management. The split from Barnum itself generated profitable publicity. Dickinson attended a Lind performance in Northampton shortly thereafter, on July 6, 1851. Her letter describing that concert shows Dickinson's awareness of the opportunities and pitfalls attending participation in commercial systems of artistic expression.

Higginson and Lind are among the public figures who provided guidance for a distinctive quality in Dickinson's writing: her exploration of the boundary between private and public. Dickinson writes always with an audience in mind, but to the extent possible it is an audience of her own making. Dickinson writing into existence her community, like the birds in her poems and letters singing theirs into being, is not merely a metaphorical relationship. For Dickinson, birdsong functionally integrates private and public: birds may sing to and for themselves, they may intend their songs to be heard by specific listeners, but ultimately they have little control over who listens. Music-making during Dickinson's lifetime similarly troubled boundaries between private and public. Musical performance took place both in homes, within family and friendship networks, and in public settings. The parlor pianist, in other words, participated in the kind of private-public network of exchange that feminist critics have long associated with the writing and publication practices of nineteenth-century "poetesses" such as Lydia Sigourney, Frances Osgood and, later, Emily Dickinson and Helen Hunt Jackson. ${ }^{3}$ Dickinson birds are cognizant of their audiences, as she was of hers. Birds would not live long if they were not aware of listeners, avian and human, in their surroundings. Similarly, a human singer-writer wanting to build an audience, especially on her own terms, needed to remain aware of the listener-readers to her utterances-texts. Dickinson slowly developed her readership by writing to - and sometimes insisting on readings and responses by - her correspondents. She identified and cultivated readers by writing, as her birds identify and cultivate listeners by singing.

\footnotetext{
${ }^{3}$ See Walker, The Nightingale's Burden, Chapter 2, "Founding the Tradition," on early nineteenth-century poetesses, and Chapter 4, "Tradition and the Individual Talent," on Dickinson. See also the chapter "These Flames and Generosities of the Heart," in; Susan Howe's The Birth-Mark, Martha Nell Smith's Rowing in Eden,; Werner's Emily Dickinson's Open Folios.
} 
This dynamic can be seen in a brief letter Dickinson sent to Josiah and Elizabeth Holland, probably in summer 1862 (L269). ${ }^{4}$ Dickinson begins the letter by reminding the Hollands that they have not written to her. Then, Dickinson refers to three birds in succession. The first two are identified as distinctive bright-colored species, atypical for Dickinson. These are set up as foils, models of unsociable behavior, with which, it is clear, she does not identify. The third, with which she clearly does, is of an unnamed species and humble circumstances. Performatively grappling with her impulse to contact the Hollands again, Dickinson externalizes this struggle sequentially onto the three birds. She says, bluntly, "Cardinals wouldn't do it." The next bird, a peacock, offers her advice, and "tells me not to inquire again." 5 These bright and showy species, atypical for Dickinson, symbolically represent social labor, but their seemingly conventional symbolic associations function unconventionally. The cardinal's strut and the peacock self-protective silence are not abstracted character flaws to avoid, but possible responses Dickinson considers and finds insufficient to the situation. Naming them allows Dickinson to stake out a rhetorical middle-ground between the sharpvoiced, disaffected cardinal, and the extravagant, faux-indifferent peacock, obliquely insisting on a response, while seeming to make no demand.

By contrast, the final bird remains anonymous, its species unnamed. This bird does not offer advice at all. Instead, it speaks for itself, articulating a statement of purpose, one that Dickinson implicitly takes up as her own. Through an utterance she attributes to the anonymous bird, Dickinson represents singing as a form of business. This appearance, in the letter's second half, seemingly out of nowhere, mirrors her own apparent surprise at encountering the bird in her garden. Dickinson writes that she

found a bird this morning, down — down - on a little bush at the foot of the garden, and wherefore sing, I said, since nobody hears?

One sob in the throat, one flutter of bosom-"My business is to sing" - and away she rose! How do I know but cherubim, once, themselves, as patient, listened, and applauded her unnoticed hymn?

Emily. (L269)

\footnotetext{
${ }^{4}$ The manuscript is missing, and may date from as early as 1859. Thomas Johnson's dating was "by conjecture only," based on his association of the phrase "a world where bells toll," with the sounds of war (L269n). Given the letter's references to "business," another possibility is that the phrase refers to the world of work. Nineteenthcentury factories often rang bells to mark the beginning and end of the workday. Dickinson's extant correspondence with the Hollands begins in 1853, and ends with Dickinson's death in 1886. Dickinson was closer with Elizabeth, but Josiah was a professional editor and a popular writer.

${ }^{5}$ The cardinal appears only twice in poems by Dickinson, late in life, once as a representation of the color red in a flower ("White as an Indian Pipe" F1250), the other representing quick arrival and departure ("Fellow/Image of Light" F1586). The peacock also appears in only two poems, both early ("If this is 'fading'" (F119), describing a showily sentimental welcoming of death, and "Some Rainbow - coming from the Fair" (F162), representing an extravagant purple among the colors in a sunset. These poems are dated by Franklin 1859 and 1860, respectively, and both are dated 1859 by Johnson. This may indicate that the earlier date for Letter 269 is more accurate.
} 
This bird, unlike the preceding two, sings a surprising, unexpected, direct, declarative song. Dickinson restates, or translates, the fleeting and extemporaneous song for the Hollands. She attributes to the song a meaning which she communicates to her correspondents, implicitly self-identifying with that meaning. The song is a statement of purpose, and its startling intensity invites, even compels the listener to participate, as well, if only to ask, "what is $m y$ business?" The bird's song opens a network of communication, which Dickinson delineates and widens through the act of writing. This trans-species song, in other words, does a sort of identifiable work, with the bird-singer representing Dickinson's own ambitions. Just as the bird has sung its business into being, Dickinson creates hers through writing. Doing so induces a corresponding labor from her readers: to write back to her, keeping intact the network of communication which encompasses the Hollands and herself. In Dickinson's anecdote of the unidentified bird, singing as " $[m] y$ business" is public - audible, declarative, translatable - and productive of work, while remaining hidden-away or only fleetingly visible, surprising, and unexpected.

\section{"My business is to sing": Emily Dickinson, Jenny Lind, and the commerce of sentiment}

Dickinson's birds sing spontaneously. In doing so, they make use of Romantic and sentimentalist tropes of the songbird, offering unfiltered, inthe-moment feelings. The figure of Philomela, the woman as a nightingale rhetorically maimed and silenced, has been critically associated with the musician and poet constrained within the nineteenth-century family parlor. Yet, if the poetess was popularly understood to be an anonymous amateur, plenty of women writers, such as Lydia Sigourney and Helen Hunt Jackson, were professionals, public figures, even celebrities. Dickinson's approach to her writing career was different. She too made use of the figure of the anonymous songbird. Yet the spontaneity of Dickinson's songbirds birds, surprising, unexpected, but socially embedded and communicative, stands in contrast with sentimentalized ideas of birdsong as artlessly, unconsciously natural and private, rhetorically constrained to the family parlor (Small Positive 31-34). In the poem quoted in this essay's title, Dickinson's oriole sings "the same, unheard,/As unto crowd - " (Fr402). Given a choice between singing in public and private, this is a refusal of the distinction.

In Dickinson's letter to the Hollands, the bird's statement, "My business is to sing" can be read in two ways. The first emphasizes "my," in the familiar sense of property, privacy, or responsibility. The bird's singing is not dependent on anyone else's permission, whether human or angelic. The second notices the unusual word "business," where a word like "art" or "passion" might be expected (or "habit" or "instinct," in a scientific or journalistic 
account). The eight definitions of the term in Noah Webster's 1828 dictionary focus not only on paid occupations, but also on unpaid work that involve seriousness of purpose and consistency of practice ("Business"). ${ }^{6}$ Webster's conceptual capaciousness accords with Dickinson's use of the word. Business is work carried out for its own purposes, whether to make a living or to achieve more personally determined, noncommercial ends. It is selfcontained, self-generating, and social. Business is what one gives sustained attention to, alongside or in connection to others.

In describing its song as business, Dickinson puts the bird to work in a way atypical for a nineteenth-century poem or a letter between friends, and associates its song with her own work as a writer. The anonymous bird is of a type Dickinson returns to again and again. ${ }^{7}$ It does not sing for Dickinson, but the act of singing invites her participation. Birds sing to one another across long distances, both because they move from place to place, and because their songs travel far. They control what, when, and to an extent how they sing, but their songs, once uttered, can be heard by anyone who happens to be present. Dickinson, too, communicates across geographical distance - in her case, through the mail - for an intended audience, but once sent, the writing passes out of her control. After their posthumous publication and donation to archives, of course, their audience grew still further. Readers such as us were never their intended audience. Yet, even during her lifetime, manuscripts she had sent to friends were shared within their personal networks.

Dickinson's semi-private network of literary affiliations that differs, in important ways, from recognized literary circles such as the Knickerbockers or the Transcendentalists. Such circles often rose up around particular publications: for example, the Transcendentalists and the Dial. ${ }^{8}$ They were largely male-originated and male-dominated. They relied on physical proximity. Dickinson's letters allowed her, over time, to develop networks of affiliation independent of geographical constraints and commercial publication systems, and to affiliate across gender and professional status. In avian terms, she flitted as she wished from correspondent to correspondent, and sang across audiences. Her letter to the Hollands provides an example. For Josiah, writing was a commercial matter, while Elizabeth Holland was a nonprofessional, a writer from the parlor. Dickinson's bird communicates

\footnotetext{
${ }^{6}$ Among the definitions are, "Employment; that which occupies the time, attention and labor of men, for the purpose of profit or improvement," "Serious engagement; important occupation, in distinction from trivial affairs" and "Duty, or employment that duty enjoins." For Webster, business cuts across social classes, encompassing "agriculture, trade, mechanic art, or profession."

${ }^{7}$ It is typical of Dickinson's birds in several respects. It is small, visually plain or nondescript, lives close to home and near the ground, and sings a remarkable, meaningful song. See, for example, "The most triumphant/Bird" (F1285) and "I was a phebe - nothing more - " (F574).

${ }^{8}$ See, for example, Douglas Dowling's The Business of Literary Circles in Nineteenth-Century America on these more familiar networks of literary affiliation.
} 
her, and the poet's, "business" across this professional/personal divide, irrespective of the readers commercial interest or affiliation.

Dickinson's birds live, work, and sing within self-defined communities that, in some respects, mimic the population and interactions typical of a small town like Amherst. The birds represent a variety of familiar characters engaging in a wide range of work activities. They include choristers, soldiers, judges, and farmers. The work of a particular species may differ across manuscripts, or even within a single manuscript. For example, in one manuscript of "A bold, inspiriting bird is the jay" (Fr1022), the jay is both a "Brigadier" and, in two of three surviving manuscripts, an "executive" and a "Magistrate," his song as "Bold as a/Bailiffs Hymn," with "Warrant in/ every Line - ." In "The robin is a Gabriel" (Fr1520), the common yard-bird's "Dress denotes/him socially" as a member of the avian "Working Classes - " whose "punctuality" and "small but/sturdy Residence" is typical "Of the New England/Farmer - ." In a shorter variant, the robin is "a Troubadour/In humble/Circumstances - ." These representations show Dickinson's awareness, and sometimes playful transgressions, of the subtle and unspoken class distinctions inherent in small-town life, and the ways individuals themselves can transgress or elide those distinctions, playing several roles at once.

Dickinson's birds enact the kind of boundary-crossing communication in which she engaged, by letter, with her geographically diffuse, self-created community of correspondent-readers, including male professional writereditors. Identities delineate and reinforce distinctions of class and access to power and influence, yet identities are not fixed: birds, like people, can play different roles depending how and when they engage with a given network. Dickinson's demand for a response from the Hollands, wealthy and influential in the realm of publishing, strategically negotiates her position. She ironically establishes her authority in her self-selected community of writers through strategic use of well-established conventions of feminine epistolary self-effacement, such as her expression of concern for "tiny" Elizabeth's health, and an exaggerated worry that her request is laughable.

In stating its business, the anonymous bird in the Holland letter sobs and flutters its bosom, hinting at Dickinson's awareness of familiar sentimental poetic tropes, and highlighting a tension between sentimental self-expression and the commerce surrounding expressive art. This awareness may be seen in Dickinson's response, in a letter to her brother Austin, to attending a concert by Jenny Lind, July 3, 1851 in Northampton, Massachusetts (L46). Lind was a renowned coloratura soprano, popularly known as "the Swedish nightingale." The unprecedented success of her performances in Britain between 1847 and 1849 drew the attention of P.T. Barnum, who contracted with Lind for an extended tour of the United States and Cuba, beginning in September 1850. The singer was marketed as a sentimental heroine, unconcerned with the wealth accruing from her singing career. Ironically, this 
public unconcern with the business aspect of performance was central to her success. Barnum arranged and managed the first half of the tour and received much of the credit - and blame - for its unprecedented box office receipts, as well as the charges of hype and hypocrisy that followed.

In practice, Lind herself was a savvy strategic manager of her career, well before Barnum ever heard her name. Lind's nearly total retirement from the stage at age thirty-two is usually cited as evidence of her indifference to finances, a turning-away from the morally compromised business of singing, as represented by Barnum. Yet her retirement at that young age was only possible because Lind had accumulated and invested a lifetime of money by then. If singing is business, Lind, may have been the most capable businesswoman of her generation. ${ }^{9}$ Dickinson's letter comments skeptically on the rhetorical distance between the public understanding of Lind as a performer virtuously indifferent to money, and the substantial box office receipts from the concert in Northampton, describing the latter as a "mistake arithmetical." Judith Pascoe has argued that Lind's performance in Amherst, her wearing of white, and her subsequent retirement and seclusion had "a complex and enduring impact on her conception of herself as an artist" (2). Yet Dickinson had no further comment on Lind after 1851. She did not take to wearing a white dress until many years later. Lind herself was less reclusive after her tour of the U.S. than commonly understood. She continued to perform, if less frequently, for years afterward. For example, the December 22, 1855 Illustrated London News contains a review of a recent concert ("Jenny Lind at Exeter Hall"). If Lind had an enduring legacy for Dickinson, it may have been a heightened awareness of the tricky line, in commercial artistic production, between public image and private business practices.

Like Lind, many women writers turned to their profession from financial necessity, yet self-presented as unwilling participants in its business aspects. Helen Hunt Jackson, born in Amherst just two months before Dickinson, suffered still greater deprivations. Orphaned at age seventeen and widowed at thirty-three, Jackson wrote and published for money, wealth and fame. Popular literary works of the time, such as Susan Warner's 1850 The Wide, Wide World, were based on the commonly-understood premise that such sudden reversals of fortune were common. Well aware of this, and as a result of her family's own financial difficulties during her youth, Dickinson had every reason to also be aware of finances. Dickinson was not in need of an earned income, yet she understood the creative economy of her time. Her

\footnotetext{
${ }^{9}$ For example, while on tour in England in 1849, Lind became romantically involved with "a young captain in the Indian army," but refused to marry him in order to retain "the power to make her own engagements and control her earnings" (Ware and Lockard 65). Ware and Lockard also document the advantageous terms she negotiated with Barnum for her U.S. tour (72), and quote Lind on investing "at interest here in America ... very safely and advantageously" (86).
} 
positive choice to renounce commercial publishing required not ignorance of but alertness to the economy of print.

What Dickinson shared with musicians such as Lind, and writers like Jackson and Warner, was an acute awareness of, and attention to, audience. Her letters, including those to the Hollands and Higginson, suggest that, in the years around the beginning of the Civil War, Dickinson used epistolary communication to establish the fundamental characteristics of her own writing business. Dickinson's first of many letters to Higginson was written in April 1862 (L260), in response to his Atlantic essay, "Letter to a Young Contributor," and around the time his article about birds appeared in the Atlantic Monthly. Her fourth letter to him was written in July 1862. As Thomas Johnson points out, some language in Dickinson's letter to the Hollands is echoed in a passage in this July 1862 letter. In the Holland letter, she describes her business and mock-worries about eliciting laughter. In the Higginson letter, she writes, "Perhaps you smile at me. I could not stop for that - My Business is Circumference - " (L268). This echoing locution, in a letter to another professional writer-editor, suggests that, in the years around the beginning of the Civil War, Dickinson was concerned with defining the fundamental characteristics of her business. ${ }^{10}$ In these letters, she anticipates possible effects of her communication, and makes clear her intention to continue, even if her correspondents think her ridiculous and, implicitly, regardless of whether they consider her marketable.

Put simply, in these two letters Dickinson asserts that she is taking up the business of writing. Not coincidentally, the majority of her print appearances took place in the years surrounding these letters, between 1858 and 1866, with nearly half in 1864. Holland was an editor at the Springfield Republican during the years 1852 to 1862 (and quarter-owner of the paper for part of that time), when four of her poems were published anonymously there (Merriam I 58). No record exists of Dickinson requesting from Holland and Higginson opportunities to print, much less pay for her writing. Instead, she requests opinions, and therefore, implicitly, recognition of herself within community of writers.

In her letter to Higginson, Dickinson's use of the word "circumference" merits attention. Laura Gribbin describes Dickinson's “idiosyncratic" use of the term as "usually ... read as a limited affirmation of humankind's ability to experience the sublime" (1). Gribbin contests the association between Dickinson's transgression of circumference and experience of the sublime, but does not challenge the underlying presumption that, for Dickinson, circumference refers to boundaries between inside and outside,

\footnotetext{
${ }^{10}$ The Higginson letter appears immediately before the one sent to the Hollands in The Letters of Emily Dickinson. The dating of the Holland letter is conjectural, however, and its proximity to the Higginson letter uncertain. Still, even if they were written across a period of three years, the concern with describing her work in terms of business, is striking.
} 
"the borderline of symbolic and linguistic order" (2), and their possible permeation. Yet the word in context, within this letter, signals that Dickinson intends the word to refer not to abstracted boundaries between "emotions, experience, language, and poetry" on one side, and "death, eternity, and the sublime" (17) on the other. The paragraph in which the word appears is concerned with earthly and even mundane matters. Dickinson is proposing the terms by which Higginson will serve as her "Preceptor," or teacher. She is writing, essentially, a business proposal. Dickinson signals to Higginson that, in writing to him, she situates him within her circle of affiliation, whether he smiles at her, admiringly, condescendingly, or not at all.

Yet her use of the word is more complex still. Circumference can define not only boundaries, but also origins, trajectories, and destinations. Circumference implies motion, even if circles always end where they began. (Properly speaking, they have no defined beginning or end, except where the pencil touches and leaves the paper.) The motion of the lines that define circles is indirect but predictable, not random. Their ability to define an area, and contain or exclude, also implies an ability to move around obstacles, to circumvent. Given Dickinson's characteristic style when communicating with professionals - a style frequently described as elliptical - as opposed to her style when writing to close friends and family members, she offers Higginson fair warning that she will speak to him indirectly. The effect of an elliptical, or circumferential, style is to frustrate definitive conclusions. She seems to say, "It doesn't matter whether you find me amusing. I will go around you if I can't go through you." Finally, Dickinson extends networks of communicative to include indirect, asynchronous modes: not limited by planned or chance in-person meetings, as in the case of a more traditionally understood literary circle, or in Dickinson's encounter with the anonymous bird, but physically distant, volitional, indirect, and beyond the boundaries of familiar social norms, like a woman in a small town writing to an Atlantic contributor. As a migrating bird flies up and over houses, trees, and telegraph lines, traveling long distances efficiently but not necessarily in a direct line, and then returning, even if by a different route, to the place of origin, so Dickinson's communications with Higginson might travel elliptically or circumferentially through the U.S. Mail. By contrast, Higginson, like Holland, was more accustomed to a method of communication exemplified by his April 1862 Atlantic essay "Letter to a Young Contributor," addressed (despite its use of the singular in the title and its personal tone of address) to many. Yet Dickinson took his invitation literally. This initiated their correspondence. Rather than participate in the impersonal, broadcast communication exemplified by the Atlantic, Dickinson took up the circumferential communication, the back-and-forth, which had been implicit in his title and tone. 
Dickinson is particularly sophisticated when it comes to playing with and against the conventions of the letter. As Martha Nell Smith has pointed out, Dickinson consistently "pushes the bounds of genre," treating "letters as poems, poems as letters," requiring readers to "question overly neat categories of genre" that consider one more or less worthy of critical attention than another (Smith 107). Here, she provides the writer-editor Higginson the opportunity not merely to read and reply to her words, as he might in response to a more conventional response letter, but also to recognize, appreciate, and interpret her writing across generic forms. Simply by reading her letter, he becomes more deeply enmeshed within her "circle," just as the surprising song of the anonymous bird in the Holland letter affiliates Dickinson herself with the bird, and her representation of that song to the Hollands affiliates them, too, with both. Higginson, a man and a public figure - a clergyman and abolitionist whose sermons had been published fits easily into a more traditional conception of a professional writer than Dickinson. For her, the business of writing is rather more custom-built, selfgenerated through her community of correspondents. It is through letters such as those to Higginson and the Hollands that her writing project advances. She constitutes that project as a business, writing, in a tone of appointment-setting, that Higginson has "much business, beside the growth of me." She places herself within the circle of his responsibilities, directing him to "appoint, yourself, how often I shall come - without your inconvenience."

\section{Thomas Wentworth Higginson, ornithology, and birdsong as improvisation}

Thomas Wentworth Higginson's essay "The Life of Birds," was published in the September 1862 Atlantic Monthly, early in a long career as a writer and editor. It shows that, like Dickinson, he was a careful observer of birds and their ways, with a similar habit of poeticizing their songs. Higginson resided in large cities including Boston and Worcester for much of his life, but the easy familiarity with which he wrote of "song[s] with wings" (362) indicates that he spent much time outside, listening, in the fields and forests of Massachusetts. Higginson's essay makes clear the similarities and differences in Dickinson's and Higginson's understandings of birdsong as emblematic, effective communication. Higginson and Dickinson both understand birds to live within communities, and to communicate meaningfully with one another in those communities, and both writers acknowledge that birdsong is work, a form of extemporaneous song-making. Still, they characterize that work differently and, for Higginson, the kind of cross-species communication and community-making that Dickinson attributes to birdsong is not possible. Ironically, Higginson's own account 
includes an description of a bird's song that he present in the English language. Yet he insists that birds and people live in separate semantic worlds, and refuses the possibility of cross-species communication. Higginson's imagined bird societies are not only apart from, but also implicitly lesser than, human communities. Such a hierarchical understanding of the relationship between people and birds makes the latter more difficult to identify and sympathize with, and for Higginson, communication among birds is not only different but lesser, even comical.

"The Life of Birds" describes the songs and behaviors of many species that also appear in Dickinson's writing, including the hummingbird, oriole, meadowlark, and bobolink. Higginson also describes the veery, brown thrasher, and wood thrush, all - as is common in Dickinson's bird poems - small in size and tending toward plain coloring. His essay repeatedly calls attention to the contrast between these birds' humble appearances and nesting sites, and the striking beauty and variety of their songs. For example, he writes of encountering two song sparrows, a species that is visually nondescript and "seeks the ground" when nesting (370). The two displayed "not the slightest difference of marking, even in the characteristic stains upon the breast, who yet chanted to each other, for fifteen minutes, over and over, two elaborate songs which had nothing in common" (372). He writes of finding a colorful hummingbird where it is least expected, sitting beside its nest "in some gray and tangled swamp" (368). (Dickinson later wrote memorably, if more conventionally, in "A rush of cochineal," of the hummingbird as an exotic traveler (Fr1489). Higginson, however, is inclined to emphasize the difference, the mutual unknowability of birds and people. "So remote from ours their mode of existence," he wrote, "they seem accidental exiles from an unknown globe, banished where none can understand their language; and men only stare at their darting, inexplicable ways, as at the gyrations of the circus" (368). For Higginson, birds live on a different stratum than humans, as circus acrobats do, with their own ways and norms. Like circus performers, they are implicitly always preparing to perform, or performing, for a human audience. He writes of the catbird, a species capable of almost infinite variability in song, as an clownish improvising musician "twittering busily, in subdued rehearsal, the whole copious variety of his lay, practicing trills and preparing half-imitation, which, at some other time, sitting on the topmost twig, he shall hilariously seem to improvise before all the world" (373). Faking it, in other words: the catbird hides away like, for example, a parlor pianist, absurdly practicing its song so it can appear to sing spontaneously in public. The bird-circus is an illusion, and the catbird's improvised singing performance, however impressive it may appear, is a sham. By contrast, as I have argued, Dickinson accepts birds as she encounters them, whether in an open yard or in a bush at the 
bottom of her garden, and she sees private practice and public performance as an interrelated whole.

Higginson, like Dickinson, contends that birds communicate through song. What humans hear as a "tumult of music" and "confused chorus" is for birds "not merely the highest form of animal language, but, in strictness of etymology, the only form, if it be true, as is claimed, that no other animal employs its tongue, lingua, in producing sound," according to Higginson (371-372). He attempts to verbally represent eight different songs made by a robin in an oak tree,

(Before noticing me,) chirrup, cheerup;

(pausing in alarm, at my approach,) che, che, che;

(broken presently by a thoughtful strain,) caw, caw;

(then softer and more confiding,) see, see, see;

(then the original note, in a whisper) chirrup, cheerup;

(often broken by a soft note,) see, wee;

(and an odder one,) squeal;

(and a mellow note,) tweedle,

implying that these were only a small number of those the bird was capable of making. He concludes "that it seemed almost impossible to doubt that there was some specific meaning, to him and his peers, in this endless vocabulary" (372). But, as the phrases "tumult of music" and "confused chorus" make clear, he makes no pretense to understand the songs. The songs are meaning-making utterances, but only from bird to bird. For Higginson himself, they are noise. ${ }^{11}$ In her letter to the Hollands, by contrast, Dickinson presumes to translate the bird's song into human words, and to present it as an instance of trans-species communication. She does not limit herself to describing the song from the rhetorical distance of the impartial observer, as Higginson does. This is why her description reads as an identification with the anonymous bird. Higginson is appreciative, but cannot interpretively enter into the experience, constraining his identification with the birds he observes. He seems not to understand, or he wants his readers to believe he cannot understand, the essence of the meaning behind the songs he hears, even though, by his own account, the robin sings some of its songs in response to his presence, "(Before noticing me)" and "(pausing in alarm, at my approach)."

\section{Joy, improvisation, and the work of song-making}

Dickinson's oriole, and the anonymous bird in her letter to the Hollands, sing songs that bridge the private and public realms, largely indifferent to

\footnotetext{
${ }^{11}$ On the distinction between noise and music, see the concise definitions of the two terms in Novak and Sakakeeny, Keywords in Sound, "Music" (112-124), and "Noise" (125-138).
} 
whether their listeners are a self-selected, private audience or a public one, while Higginson's catbird behaves differently in private and in public. Yet Higginson and Dickinson also share a foundational understanding of birds and their songs. The first sentence of "The Life of Birds" begins, "When one thinks of a bird, one fancies a soft, swift, aimless, joyous thing ...." (368). As Judy Jo Small points out in Positive as Sound, Dickinson's birds are as likely to sing for joy as for sorrow (34). The word appears again and again in Dickinson's bird poems. The bobolink sings for pleasure in "The way to know the bobolink" (Fr1348), and provides the relief of an "anodyne" or opiate in "No bobolink reverse its singing" (Fr766). Dickinson's bluebird also sings for pleasure in "After all the birds have been investigated" (Fr1318), and goes "buccaneering" across the sky in "We like March - his shoes are purple" (Fr1194). An airborne traveling salesman, the bluebird carries "specimens of song/As if or you to choose - " ("Before you thought of spring" (Fr1484)). But, left to himself, he needs no audience, finding a high tree "Without a single Leaf," he

Shouts for

joy to nobody

But his

seraphic

Self - .

Whatever their embeddedness in their communities, can it be argued that Dickinson and Higginson, in positing that birds sing for "joy," reenact the sentimentalist tendency to idealize their songs as natural and artless? ${ }^{12}$

Higginson knew birds, and he knew improvisation. He was a skilled oratorical improviser who, as a New England clergyman and abolitionist, would also have heard many others offer extemporaneous sermons and speeches. ${ }^{13}$ In writing of the catbird, in "The Life of Birds," he accurately describes that species' capacity for extemporaneous variations in its song. Like the Euro-African nightingale and the mockingbird, whose typical range is further south (and was further south still in the nineteenth-century, prior to the effects of climate change), the catbird is known for the almost infinite variability of its songs, its ability to mimic the songs of other birds, and its tendency to combine and recombine in different orders its own and others'

\footnotetext{
${ }^{12}$ Ornithologists remain puzzled about whether birds sing for pleasure. It is more common to attribute singing to mating or territorial defense. Yet, in Why Birds Sing, the philosopher and musician David Rothenberg notes that at least some birds do seem to sing for their own pleasure, and not only to seek a mate or demarcate territory. For example, the mockingbird, equivalent to the catbird in song variety and mimicry ability, sings into its territory. As Higginson noted, male song sparrows gather in groups to trade songs, even after mating and nest-building have taken place and no threats are present (118-119).

${ }^{13}$ Two of Higginson's "extemporaneous" lectures can be found in The Rationale of Spiritualism, and he wrote of speaking "naturally" and "without notes" in Hints on Speech Making.
} 
songs, making the familiar new through recontextualization. Unlike the others, though, the catbird has a default song, "disagreeable and catlike," so that the richness of its improvisational ability is especially surprising (Clark 92). It is strange that his narration so harshly judges the catbird for seeming to practice in private and then seek the topmost twig to sing. The implication is of vanity and hypocrisy. The bird's "subdued rehearsal" of its song's "copious variety" is all meant to gain renown when transferred to "the topmost twig," where the bird only "seem[s] to improvise" ("The Life of Birds" 373). Higginson implies that he sees through the "hilarious" ruse of the accomplished bird-singer, and we should, too. for those who have eyes as well as ears.

Dickinson, unlike Higginson, was largely indifferent to the topmost twig. On at least one occasion, she actively resisted the request to submit a book manuscript. ${ }^{14}$ In general, however, Dickinson's writing practice demonstrates that she treated public and private not as separate spheres, but as an interrelated whole. In musical terms, she deemphasized the distinction between practicing and performing. The manuscripts she preserved for her own use gather ideas, much like a working musical improviser's annotated sheet music, and those she sent to others are like extemporaneous performances. ${ }^{15}$ Twentieth-century critics of nineteenth-century literary and musical cultures describe a separation between a public sphere, inaccessible to women, and a private one, where women's creative practices necessarily took place. While literary studies have complicated this understanding in recent decades, it has continued to inform critical understanding of women's place in nineteenthcentury musical life. ${ }^{16}$ One way Dickinson is representative of her time is in her skillful navigation of a borderline between private and public that was more permeable than has been generally acknowledged. This matters because music has been generally acknowledged as a formative creative practice for Dickinson. If her creative practice crossed boundaries between private, semipublic, and public that were increasingly available to women as well as men in the 1850s and beyond, then her writing practice fits well within the mainstream for her time, not only as a writer, but as a music-maker, as well. Dickinson experiences normative extemporaneous birdsong as integrating private and public, because that was her understanding of music-making and creative practice generally. Higginson, by contrast, imagines the emblematic catbird's improvised song as split between private preparation and public trickery, intended to fool the audience into believing in the illusion of extemporaneity.

\footnotetext{
${ }^{14}$ Thomas Niles of Roberts Brothers asked her for "a M.S. collection of your poems, that is, if you want to give them to the world through the medium of a publisher" in L813b, to which editor Thomas Johnson adds a note saying, "ED made no response to this request," yet her opening line in L814, "Thank you for the kindness," can be read as a response to Niles' request.

${ }^{15}$ I explore this theme more fully explored in a chapter, "'Discretion in the interval': Musical Improvisation and Emily Dickinson's Manuscript Variations," in the forthcoming Oxford Handbook to Emily Dickinson.

${ }^{16}$ See, for example, Slobin et al., Emily's Songbook and Meyer-Frazier, Bound Music, Unbound Women.
} 
In Dickinson, birds are not merely part of the poetic scenery, and their songs are more than background noise in the soundscape. She knew birds, and they do work in her poems. They speak on her behalf, articulating an idea about writing as work, as a practice that constitutes a kind of business, but outside of, and largely indifferent to, the business of commercial publishing. In this, she is similar to, but apart from, her correspondents Helen Hunt Jackson, Josiah Holland, T.W. Higginson, and Thomas Niles.

The catbird, the star of Higginson's "The Life of Birds," is not mentioned in any of Dickinson's extant writings. This is odd, because it is similar, in several respects, to many of the bird-species about which Dickinson wrote. It was and remains an "abundant summer resident" in New England (Clark 92). The variability of its song is surprising, because it is visually rather nondescript, gray with a black cap and, in males, a reddish-brown underside that temporarily grows brighter during mating season. Most of all, it does not need an audience, as the first part of Higginson's anecdote makes plain. As David Rothenberg pointed out, mockingbirds are known to sing into their territory: that is, away from potential mates or threats. Like Dickinson's anonymous songbird, it seems they sing whether there is an audience or not. It is Higginson who interprets the catbird's song, when it is "concealed in the middle of a dense bush," as "subdued rehearsal" (Higginson "The Life of Birds" 373). For Dickinson, audience matters, but a performance for a single reader or listener is as much a performance as one for thousands, and whether heard or overheard. Dickinson signals her awareness of this "commonness" in her letter to the Hollands, and states her point more explicitly in "To hear an Oriole sing" (Fr402):

To hear an Oriole sing

May be a common thing -

Or only a divine.

It is not of the Bird

Who sings the same, unheard,

As unto Crowd -

The Fashion of the Ear

Attireth that it hear

In Dun, or fair -

So whether it be Rune -

Or whether it be +none

Is of within. + Din. 
The "Tune is in the Tree -"

The Skeptic - showeth me -

"No Sir! In Thee!"

For Dickinson, our hearing of the bird's song is subjective, iterative, interpretative, rune or din depending on who is listening and interpreting. The bird sings the same whether alone or before a crowd. There is a value judgment implicit in the initial options Dickinson presents as available to listeners. The bird's song may be "a common thing - /or only a divine," a lesser status, according to the conventions of listening, or to say it differently, according to the collective understanding of the listeners to the song. It may be "Rune," a carrier of interpretable material, or "none." (According to the interpolated variant word, it may even be "Din," as birdsong sometimes seems to be for Higginson. He could be speaking the third to last line, "The 'Tune is in the Tree - '," while Dickinson could be "The Skeptic" asserting that it is "'In Thee!"” The "specimens of song" carted around by the traveling-salesman bluebird is another instance of a bird indifferent to the presence or absence of audience. Like Higginson's catbird, he sings from high in a tree, but "to nobody/But his/seraphic/Self - " (Fr1484).

\section{Works cited}

Clark, Hubert Lyman. The Birds of Amherst and Vicinity. Including Nearly the Whole of Hampshire County, Massachusetts. With an Introduction by Professor Charles H. Fernald, PH.D. Carpenter \& Morehouse, 1906.

Dickinson, Emily. The Letters of Emily Dickinson. edited by Thomas Herbert Johnson and Theodora Van Wagenen Ward, Belknap P of Harvard UP, 1986.

- The Poems of Emily Dickinson. edited by R. W. Franklin, The Belknap P of Harvard UP, 1998.

Dowling, David Oakey. The Business of Literary Circles in Nineteenth-Century America. Palgrave Macmillan, 2011.

Erkkila, Betsy. "Emily Dickinson and Class." American Literary History, vol. 4, no. 1, 1992, pp. 1-27. doi:10.1093/alh/4.1.1.

Higginson, Thomas Wentworth. Hints on Speech Making. Longmans, Green and Co., 1887. Reprinted 1903.

- The Rationale of Spiritualism: Being Two Extemporaneous Lectures Delivered at Dodsworth Hall, December 5, 1858. T.J. Ellinwood, 1859.

- "Letter to a Young Contributor," Atlantic Monthly, vol. 7, no. 54, Apr. 1862, pp. 401-11.

—. "The Life of Birds." Atlantic Monthly, vol. 10, no. 59, Sep. 1862, pp. 368-76.

Howe, Susan. The Birth-Mark: Unsettling the Wilderness in American Literary History. Wesleyan UP, 1993.

"Jenny Lind at Exeter Hall." The Illustrated London News, vol. 27, no. 775, 22 Dec. 1855, pp. 713-14. 
Merriam, George S. Life and Times of Samuel Bowles. Century Co., 1855.

Meyer-Frazier, Petra. Bound Music, Unbound Women: The Search for an Identity in the Nineteenth Century. College Music Society, 2015.

Novak, David, and Matt Sakakeeny, editors. Keywords in Sound. Duke UP, 2015.

Pascoe, Judith. “The House Encore Me So': Emily Dickinson and Jenny Lind." Emily Dickinson Journal, vol. 1, no. 1, 1992, pp. 1-18. doi:10.1353/edj.0.0055.

Penny, Virginia. The Employments of Women: A Cyclopaedia of Woman's Work. Walker, Wise \& Co., 1863.

Rothenberg, David. Why Birds Sing: A Journey through the Mystery of Bird Song. Basic Books, 2005.

Schuman, Jo Miles, and Joanna Bailey Hodgman. "Introduction: Emily Dickinson, Intimate of Birds.” A Spicing of Birds: Poems by Emily Dickinson. edited by Jo Miles Schuman and Joanna Bailey Hodgman, xiii-xxiv. Wesleyan UP, 2010.

Slobin, Mark, et al. Emily's Songbook: Music in 1850s Albany. A-R Editions, 2011.

Small, Judy Jo. Positive as Sound: Emily Dickinson's Rhyme. U of Georgia P, 1990.

Smith, Martha Nell. Rowing in Eden: Rereading Emily Dickinson. U of Texas P, 1992.

Walker, Cheryl. The Nightingale's Burden: Women Poets and American Culture before 1900. Indiana UP, 1982.

Ware, W. Porter, and Thaddeus C. Lockard Jr. The Lost Letters of Jenny Lind. Translated from the German and Edited with Commentaries. Victor Gollancz Ltd., 1966.

Warner, Susan. The Wide, Wide World. Feminist P at the City U of New York, 1987.

Webster, Noah. "Business." An American Dictionary of the English Language. S. Converse, 1828. Reprinted in Facsimile by the Foundation for American Christian Education, 2002.

Werner, Marta. Emily Dickinson's Open Folios: Scenes of Reading, Surfaces of Writing. U of Michigan P, 1995. 